DOI: $10.30519 /$ ahtr.592312

Advances in Hospitality and Tourism Research (AHTR)

\title{
EVALUATION OF HOTEL PERFORMANCE ATTRIBUTES THROUGH CONSUMER GENERATED REVIEWS: THE CASE OF BRATISLAVA ${ }^{1}$
}

\author{
Gabriela USLU CIBERE² \\ Social Sciences Institute, Alanya ALKU University, Alanya, Turkey \\ ORCID: 0000-0002-2945-5987 \\ Murat Alper BASARAN \\ Department of Management Engineering, Alanya ALKU University, Alanya, Turkey \\ ORCID: 0000-0001-9887-5531 \\ Kemal KANTARCI \\ Department of Tourism Management, Alanya ALKU University, Alanya, Turkey \\ ORCID: 0000-0002-9572-2959
}

\begin{abstract}
Slovakia is positioned in a highly competitive market of Central European countries with geographical and cultural similarities. Despite having a good potential, the tourism development in the country has not reached the level of the neighboring countries. In information sensitive sector such as tourism, the development is highly dependent on following and implementing new trends including latest technology. The usage of social media and Travel 2.0 platforms has become crucial in decision-making about the place to go or stay and online reviews have turned into a valuable source of information about the supplier's performance and service quality. This study analyses hotel performance through hotel performance attributes using consumer generated reviews posted on the number one hotel rating social platform TripAdvisor. Hotel reviews based on real travel experience is a valuable source of information about the hotel's performance evaluated by tourists directly. Several interesting findings resulted from the research and further implications were advised.
\end{abstract}

Article History

Received 16 July 2019

Revised 19 November 2019

Accepted 17 January 2020

Keywords

hotel performance

travel 2.0

TripAdvisor

consumer generated reviews

Slovakia

\footnotetext{
${ }^{1}$ An earlier version of this study was presented at the 4th INES International Academic Research Congress, Alanya, Turkey, November 2018.

2 Address correspondence to PhD. Candidate Gabriela USLU CIBERE, Alanya ALKU University, Alanya, TURKEY. E-mail: gabriela.uslucibere@gmail.com
} 


\section{INTRODUCTION}

There is no doubt that performance measurement of a business has gained on importance in the eyes of business owners and managers in the last decades, with ever growing globalization and fierce market competition. Many authors have emphasized the intense competition in the hotel industry which makes decision-making based on sufficient performance information a necessity (Atkinson \& Brander Brown, 2001; Sainaghi, 2010; Zigan \& Zeglat, 2010; Chen et al., 2011; Kantarci et al., 2017). Performance measurement can be defined as "process of collecting, computing and presenting quantified constructs for the managerial purposes of followingup, monitoring and improving organizational performance" (Kollberg et al., 2005, p. 98). Over the last several decades, academics have developed numerous approaches to performance measurement including individual financial or non-financial measures and more holistic approaches. Atkinson and Brander Brown (2001) emphasize that a company's performance should be evaluated in relation to customer satisfaction, where perceived service quality is the driver of hotel's performance (Wilkins et al., 2007). Starting with SERVQUAL scale of Parasuraman et al. $(1988,1991)$ the perspective of evaluating service quality shifted from company's to consumer's perspective, which is accurate especially in the age of Web 2.0 technology. Hotel visitors share their experiences and opinions extensively through Travel 2.0 platforms in form of consumer generated reviews. These platforms can be considered valuable sources of information about hotels' performance mediated by consumers' satisfaction. Adding consumer's perspective into hotel performance theory is undoubtedly advantageous as several studies have proven relation of online hotel reviews and hotel's occupancy level, average daily rate and revenue per available room (Touminen, 2011); and relation between hotel rating system and hotel performance changes measured through volume of sales, average daily room rate and occupancy (Narangajavana \& $\mathrm{Hu}, 2008$ ).

The research of hotel performance adopting consumer generated review analysis is very scarce and rather outdated. Except a few studies mentioned above (Narangajavana \& Hu, 2008; Touminen, 2011), the work of Xie et al. (2016b) concentrated on managerial responses in relation to eWOM and hotel performance. Kantarci et al. (2017) analyzed consumer generated reviews of hotels, shortly CGR, in Kyrgyzstan using Log-Linear model in order to determine the influence of trip characteristics such as travel year, travel season and travel type on hotel evaluation dimensions. Jeong and Mindy Jeon (2008) conducted an analysis of New York City hotels' reviews using 8 hotel performance attributes from TripAdvisor, 
guest satisfaction and return intention evaluations in relation to hotel characteristics such as ownership, class, number of rooms, average room rate and popularity index. To our best knowledge, a more holistic research of what are the hotel attributes evaluations in TripAdvisor reviews influenced by and dependent on has not been conducted yet. Similar to Jeong and Mindy Jeon (2008) who directly accepted the 8 dimensions of TripAdvisor reviews as hotel performance attributes, the authors have decided to accept the hotel attributes in consumer generated reviews (CGRs) of hotels on TripAdvisor as hotel performance attributes. Using the wide range of standardized data provided by hotel reviews on TripAdvisor the study aims to investigate:

- $\quad$ whether there is any relation between hotel performance evaluations and demographic characteristics of reviewers (age, nationality, gender), trip characteristics (travel type, season and year) and hotel characteristics (hotel ownership and class) and

- $\quad$ which dimensions influence the overall evaluation of a hotel as a hotel's overall performance attribute.

Along with traditional performance measures, assessing hotels' performance from consumers' point of view may provide a more complete picture of a hotel's performance. As using the publicly available data on TripAdvisor is less cost and time consuming than traditional ways of opinion surveys and enables a continual monitoring of a hotel's performance, the study provides an example of extracting valuable information for hotel managers and sector decision makers that can be useful in market segmentation and targeting, formulating marketing strategies or product development and innovation and thus may lead to improving the hotel's performance.

The study is organized into four sections. Firstly, the literature review on the topic of measuring performance through hotel attributes and their online evaluation on social platforms is presented. A short introduction of Slovakia and an overview of the development of tourism in the country follows. In the second part, the applied methodology is described. The third section explains the key findings of the study followed with the final section concluding and discussing the obtained results, their practical implications and limitations. 


\section{LITERATURE REVIEW}

\section{Measuring hotel performance via hotel attributes}

In literature, three approaches to performance evaluation can be identified. Hotel performance was predominantly measured via traditional measures including financial and non-financial measures as well as more holistic evaluation scales. With the rise of social platforms, the hotel performance was evaluated via consumer generated reviews either in relation to the traditional performance measures or using it as direct representations of hotel performance attributes. The traditional ways of measuring hotel performance were based on financial statements encompassing a number of disadvantages when used as a sole method of performance evaluation (Atkinson \& Browner Brown, 2001; Zigan \& Zeglat, 2010); and several nonfinancial measures such as sales and market share growth (Harrington \& Akehurst, 1996), customer satisfaction and level of complaints (Banker et al., 2005), average daily rate and revenue per available room, occupancy of a hotel (Touminen, 2011). The more holistic balanced performance measurement systems that are related to company's strategy and customer satisfaction (Atkinson \& Brander Brown, 2001) include the performance measurement system in the service industry (PMSSI) by Fitzgerald et al. (1991) and the balanced scorecard (BSC) by Kaplan \& Norton (1992) which have been used extensively in the hospitality research (Evans, 2005; Phillips \& Louvieris, 2005; Bergin-Seers \& Jago, 2007; Chen et al., 2011).

Based on the research of Atkinson \& Brander Brown (2001), 94\% of UK hotels evaluated quality of service as a part of performance measurement although the methods are unknown. Service quality constructs were proven to be drivers of a hotel's performance by the research of Wilkins et al. (2007). Narangajavana \& Hu (2008) found a significant relationship between service quality improvement and changes in hotel performance. The SERVQUAL scale designed and refined by Parasuraman et al. $(1988,1991)$ as a multi-item scale measuring perceived service quality evaluated by consumers themselves was widely applied in the hotel industry (Devi Juwaheer, 2004; Ramsaran-Fowdar, 2007; Stefano et al., 2015) as was the SERVPERF by Cronin and Tayor (1992, 1994), although to a lesser extend (Yilmaz, 2009; Al Khattab \& Aldehayyat, 2011). Regardless of the scale, adding the customer's perspective on service quality helped acquiring a more realistic picture of hotel performance.

Following the rapid development of Web 2.0 technologies a new approach to perceived service quality and hotel performance evaluation can be identified. Consumer generated content created by consumers 
themselves represent a turning point in the hotel performance measurement through customer satisfaction and perceived service quality evaluation. Unlike the previously mentioned methods, CGRs of hotels on the Internet offer several significant advantages:

- published by consumers themselves based on real experience, they are considered largely reliable by travelers (Gretzel \& Yoo, 2008; Chua \& Banerjee, 2013);

- produce information available not only for hotel management but easily accessible to travelers worldwide and thus influence their decisionmaking directly (Kantarci et al., 2017);

- may include textual as well as visual information;

- may have structured or unstructured form. Unlike other approaches, CGR are independent from any pre-defined set of dimensions, which decreases the risk of omitting any important factor influencing the service quality and hotel performance;

- are available for any period of the year and ensure continuity;

- are more time and cost effective compared to approaches utilizing traditional consumer surveys;

- generate data for evaluation of a single hotel, hotel chain or the whole hotel sector in a destination.

Despite the numerous advantages of consumer generated content, CGRs represent very recent research field among academicians. CGRs of hotels on the largest travel-related platform TripAdvisor was studied in connection to various areas such as consumer decision-making (Vermeulen \& Seegers, 2009); credibility perceptions of CGC (Ayeh et al., 2013); customer satisfaction (Molinillo et al., 2016); eWOM, review content analysis and valence (Melián-González et al., 2013); destination image (Miguéns et al., 2008); use and impact of CGR during travel planning process (Gretzel \& Yoo, 2008); content creators' reputation (Lee et al., 2011); comparisons of independent and chain hotels (Banerjee \& Chua, 2016); offline hotel popularity (Xie et al., 2016a).

Limited number of authors has related CGR with hotel performance from different points of view. Xie et al. (2016b) paid attention to managerial response in relation to eWOM and hotel performance. Kantarci et al. (2017) analyzed CGR of hotels in Kyrgyzstan using Log-Linear model in order to determine the influence of travel year, travel season and travel type on hotel evaluation dimensions. Singh et al. (2016) studied online reviews in relation to improving hotel performance and online image. They found out that while quality of online consumer ratings influenced significantly the overall 
market rankings of hotels on travel websites, the quantity of reviews did not have any influence. Touminen (2011) studied hotel reviews on TripAdvisor and their influence on hotel performance measured through occupancy level, average daily rate and revenue per available room. His extensive research among 77 hotels in 6 different cities proved a significant positive relation between the above-mentioned hotel performance measures and number of reviews written and review average, while both of them can also significantly improve the occupancy of a hotel. Moreover, the study revealed a high correlation between recommendation percentage and occupancy of a hotel and a considerable correlation to revenue per available room. No relationship was found between TripAdvisor popularity rating and the hotel performance (Touminen, 2011). Similarly, Narangajavana \& Hu (2008) analyzed the relationship between hotel rating system, service quality improvement and hotel performance changes. The hotel performance changes were evaluated through volume of sales, average daily room rate, occupancy before and after the certification by the Thailand Hotel Standards. The research also found out that improvement in service quality led to positive changes in hotel performance.

In order to quantify the impact of consumer generated reviews on hotel performance, Ye et al. (2009) constructed a log-linear regression model and analyzed data from the Chinese biggest travel-related website. According to their results, $10 \%$ increase in online review rates leads to $4.4 \%$ increase in hotel room sales. Similarly, Öğüt \& Onur Taş (2012) found 1\% increase in online ratings resulting in up to $2.6 \%$ increase in room sales depending on the destination while Ye et al. (2011) concentrated on online sales and found that a $10 \%$ increase of review ratings cause the online bookings to rise by more than $5 \%$. Based on the Expedia internal statistics, a one-point improvement in online review rate results in $9 \%$ increase in average daily rate (Lynch, 2012). However, the authors of the current study believe that online reviews shall not be researched only in relation to traditional financial and non-financial performance measures as in the studies above. Consumer generated reviews may be accepted as digital representations of hotel performance attributes reflecting consumer satisfaction and perceived quality of a hotel as in the study of Jeong and Mindy Jeon (2008). The authors conducted an analysis of New York City hotels' reviews using 8 hotel performance attributes adopted from TripAdvisor, guest satisfaction and return intention evaluations in relation to hotel ownership, class, number of rooms, average room rate and popularity index using descriptive statistics, t-test, ANOVA and the Bonferroni's multiple group comparison method. The research is based on 
the theory that online communication sites are a primary source of information about a company's performance and they can help hospitality companies to improve their performance in the future. It is important to mention that the research included reviews from the year 2006 when the structure of reviews on TripAdvisor differed from its present form.

\section{Online evaluation of hotel performance attributes}

Consumer generated content including CGRs published in social media and Travel 2.0 platforms are especially influential in tourism because of the experience-based nature and intangibility of touristic products (Touminen, 2011). To reduce the risk, travelers tend to search recommendations of other travelers in form of CGRs during their travel planning process, which can be very influential on their purchase decision (Yoo et al., 2007; Gretzel \& Yoo, 2008; Hays et al., 2013; Munar \& Jacobsen, 2014).

According to Kantarci et al. (2017) travelers can reach online opinions of visitors easier, cheaper and faster than using any other traditional way. Travel related topics are among the most popular topics on social media $(\ddot{\mathrm{O} z}, 2015)$ and some authors consider it the major driving force that has impact on traveler's perception of a hotel (Sigala et al., 2012). Consumer generated media, especially CGR, are widely used by travelers when planning a trip as proved by several studies (Gretzel \& Yoo, 2008; Yoo et al., 2009). They are generally considered to offer more accurate, enjoyable and reliable information to travelers. The reviews are preferably searched for on virtual community websites such as TripAdvisor, which uses the same Web 2.0 technology as social media websites. Most of the travelers use CGRs in the middle stage of their travel planning to cut down choices. Almost $78 \%$ of travelers use it for deciding on the place to stay while $25 \%$ of infrequent and $33 \%$ of frequent travelers did change their hotel decisions in the past based on other travelers' reviews (Gretzel \& Yoo, 2008).

Although the SERVQUAL model of Parasuraman et al. $(1988,1991)$ can be considered a milestone in search for service attributes that determine consumer satisfaction, the model itself is hardly applicable in online service quality evaluations because of its length (22 items regarding each expectations and perception) and being time consuming and confusing for some consumers. In order to bridge the gap in quality perceptions between service providers and hotel visitors, Nasution \& Mavondo (2008) pointed out that it is vital to add consumers' perspective into hotel service quality evaluation for a more accurate picture of hotel's performance. Consumer generated reviews on online platforms provide real-time continual data on 
consumers' satisfaction and service quality, which is impossible to obtain through questionnaires or surveys (Zhang \& Verma, 2017).

Using these online data, a group of researchers continues researching and justifying hotel attributes that play important role in customers' satisfaction. The work of Jang et al. (2018) identified top 30 hotel attributes in CGRs determining the hotel ratings on TripAdvisor that were grouped into core service \& room quality, supplementary service and attributes outside the hotel categories. The authors analyzed the importance of each attribute and change of its importance over time. In conclusion, staff was found to be the most important hotel attribute influencing the hotel rating. On the contrary, Zhang and Verma (2017) proved service and rooms to be the most important attributes for high-end hotels. A research among luxury hotels in Malaysia (Padma \& Ahn, 2020) distinguished among hotel-related attributes, room-related attributes, staff-related and travel-related attributes of luxury hotel service quality while identifying quality of rooms and interaction with employees as the drivers of consumers' satisfaction. The research on identifying hotel attributes from CGRs and analysis of their importance from the consumers' point of view is quite extensive but the text mining techniques applied only explain the frequency of individual words (attributes) not their valence and miss any quantifiable evaluations, which makes it impossible to measure the actual performance of a hotel at the end. Such an approach also produces an overload of information and high number of attributes that are hard to monitor on a regular basis in practice.

On the other hand, using the standardized data included in CGRs on platforms such as TripAdvisor enables to calculate quantified outcomes and analyze any relations among variables that may influence the hotel performance attributes evaluations by consumers. Although textual part of CGRs articulates the details of a consumer's actual hotel experience, it is the numerical ratings that communicate hotels' performance in relation to various attributes (King et al., 2014). In the study, the standardized attributes of CGRs of hotels on TripAdvisor were accepted as hotel performance attributes and analyzed in relation to the overall evaluation of hotel's performance as well as to demographic, hotel and trip characteristics.

\section{Tourism in Slovakia}

Slovakia is a landlocked country in the Central Europe with a population of nearly 5.5 million. The country declared sovereignty on January 1993 (slovakia.travel, 2018). Although the country has a rich potential for tourism 
development, the Travel \& Tourism Competitiveness Index 2017 ranks Slovakia as 59 from 136 countries (World Economic Forum, 2018). Its natural resources are favorable for development of agro-tourism, rural tourism, health tourism, winter and special interest tourism. There are 9 national and 14 regional parks under protection covering almost $22 \%$ of Slovakia, 1200 mineral and thermal springs, $10,000 \mathrm{~km}$ of cycling tracks and $14,000 \mathrm{~km}$ of trekking routes and tens of ski centers, around 6000 caves 18 of which are accessible to public and unique in Europe and the world. 7 UNESCO heritage sights, together with 18 cities with well preserved and protected city centers and hundreds of castles and mansion houses, are the base for cultural and city tourism in Slovakia (SACR, 2013).

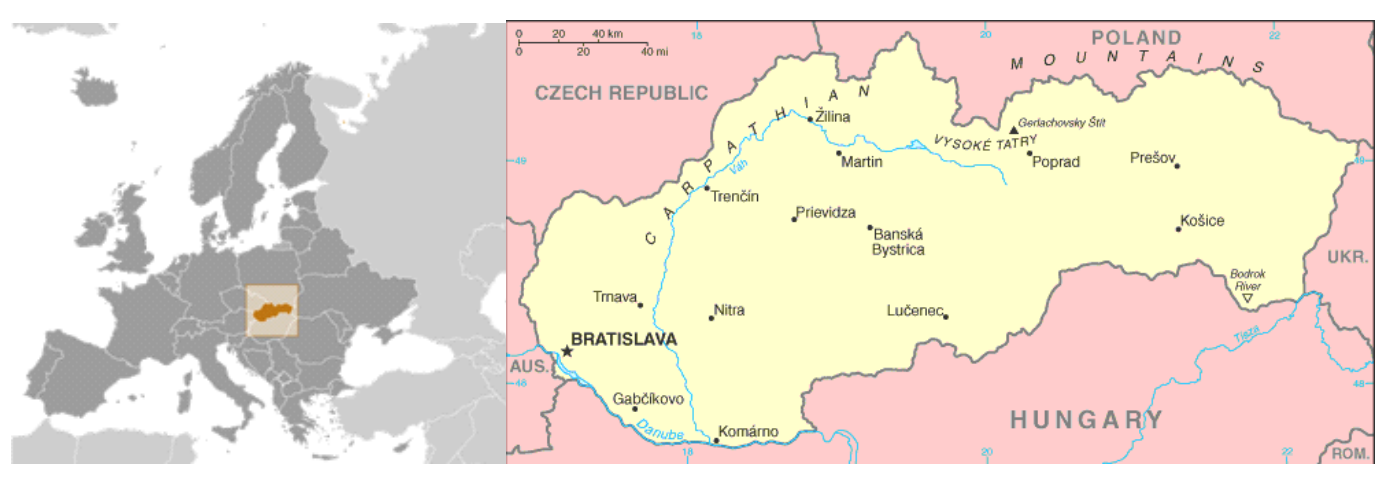

Figure 1. Map of Slovakia (Central Intelligence Agency, 2019).

The Slovak travel and tourism (T\&T) sector produced 2.2 billion EUR in 2017, which accounts for $2.6 \%$ of its total GDP. While $50.7 \%$ of it was generated by foreign visitors, remaining $49.3 \%$ was generated by domestic tourists. The total contribution of travel and tourism to GDP is estimated to be double the size of the direct contribution and in case of Slovakia it was 5.4 billion EUR (6.3\% of GDP) in 2017. Based on the total contribution of T\&T to GDP, the World Travel \& Tourism Council ranks Slovakia as 77th out of 185 countries in 2017 but it expects Slovakia to fall to 126th place within the following 10 years. The sector provided over 155,500 jobs in total (6.1\% of total employment) and visitor exports accounted for 2.4 billion EUR in 2017, which forms 3\% of total exports of the country (World Travel \& Tourism Council, 2018). The above stated indicators are forecasted to rise very insignificantly $(0.1 \%-0.9 \%)$ until 2028 so it is obvious that Slovak tourism performance does not meet its potential.

The possible reasons behind the low tourism performance and rather unfavorable development of the sector, compared to its potential, may lay 
in incomplete transition in general and in tourism, low prioritization and support of the sector from the state, slow adoption of new trends including new technology in tourism or missing continuity of tourism strategy, planning and controlling. Since the formation of the Slovak Republic in 1993, tourism has been organizationally transferred from ministry to ministry, currently belonging under the Ministry of Transport and Construction of the Slovak Republic (aices.sk, 2019; culture.gov.sk, 2019).

The outline for tourism development strategy, goals and implementation is described in the Manifesto for 2016 - 2020, the Tourism Development Strategy until 2020 and the Marketing strategy until 2020. In the Manifesto for 2016 - 2020 the Slovak government emphasizes the goals of increasing competitiveness, decreasing unemployment through creating jobs in tourism, promoting coordination between the transport and tourism sector, creating and promoting the image of Slovakia as an attractive and safe destination, attract more tourists and prolong their stay, especially support spa tourism and encourage governance through local Destination Management Organizations (DMOs).

Increasing competitiveness and better use of potential is also the core of the Tourism Development Strategy until 2020, which identifies 2 key areas of focus, i.e. quality of tourism product and attractive presentation and promotion of Slovakia (Ministry of Transport and Construction, 2013). In attempt to increase the quality of tourism offer the Ministry developed the Slovak system of quality of tourism services, which is a certification system aimed at enhancing quality and increasing competitiveness of Slovak tourism product. It enables suppliers of tourism services to gain an internationally comparable quality mark. Furthermore, the marketing strategy until 2020 and especially the updated marketing strategy for 2019 - 2020 recognizes the importance of smart technology in tourism marketing, necessity of providing personalized information to consumer and evergrowing orientation to sharing economy. In accordance with the trends, the National Tourist System has been developed as an interface for smart presentation of Slovakia integrated to the official tourism portal slovakia.travel which helps tourists to plan their trip; several region or activity based mobile applications and regional travel cards have been developed (European Commission, 2017; slovakia.travel, 2019).

Bratislava as the capital of Slovakia is the largest city of the country with a population of nearly 450,000. It is located in the South-West of Slovakia near the Austrian and Hungarian borders. The city is easily accessible by road and rail from the neighboring countries but its 
accessibility by air is limited. Close proximity of Vienna (approx. 1 hour by car) and direct highway connections to Budapest (approx. 2 hours by car) and Prague (approx. 3 hours by car) position Slovakia into an important East-West and North-South junction, which supplies high number of visitors to the city. On the other hand, however, the profile of the inbound tourists is rather unfavorable formed predominantly by one-day or shortterm visitors passing through the city and moving on to their final destination. It is so with the Central Europe tour leading through Budapest, Bratislava, Vienna and Prague which mostly include a visit to the Bratislava City with one overnight stay at most.

Table 1. Selected indicators of tourism and hotel sector development in Slovakia (2017)

\begin{tabular}{lrrr}
\hline Tourism development indicators & $\begin{array}{r}\text { Slovakia } \\
\text { (SVK) }\end{array}$ & $\begin{array}{r}\text { Bratislava } \\
\text { region (BA) }\end{array}$ & $\begin{array}{r}\text { BA / SVK } \\
\text { (\%) }\end{array}$ \\
\hline Number of accommodation establishments & 3,495 & 234 & 6.7 \\
Number of rooms & 62,658 & 9,425 & 15.0 \\
Number of beds & 160,881 & 21,046 & 13.1 \\
Occupancy rate (\%) & 31 & 41 & - \\
Number of inbound tourists & $2,162,384$ & 930,643 & 43.0 \\
Average length of stay of inbound tourists & 2.5 & 1.8 & - \\
Average expenditure of inbound tourist for & 26.6 & 35 & - \\
accommodation (EUR per night) & & & \\
\hline Source: Adapted from: Statistical Office of the Slovak Republic (2018b, c).
\end{tabular}

According to the data from the Statistical Office of the Slovak Republic (2018a), Slovakia attracted slightly fewer than 2.2 million inbound tourists in 2017. 43\% of inbound tourists visited the Bratislava region dominated by the city of Bratislava. Majority of them came from the neighboring countries (Czech Republic, Poland, Hungary and Austria), from Germany, Israel and UK. With an exception of the year 2014, number of tourists has had an increasing tendency in the recent decade reaching $6.7 \%$ growth of foreign visitors in 2017 compared to the previous year (Statistical Office of the Slovak Republic, 2018b).

Despite the increasing number of tourist arrivals, the length of stay and average expenditure per holiday decreases. The average length of overnight stays of foreigners visiting Slovakia dropped from 3.6 in 2000 to 2,5 in 2017 (Statistical Office of the Slovak Republic, 2018a). The Bratislava region is far below the average of Slovakia reaching only 1.8 nights spent by foreigners (Statistical Office of the Slovak Republic, 2018b). The very short length of stay is caused by the fact that $67 \%$ of visitors of Slovakia are 
transit or 1-day visitors while only $12.3 \%$ of visits last more than 3 days (Statistical Office of the Slovak Republic, 2016a). This indicates that, for the vast majority of tourists, Slovakia is just a transit country or a part of a trip not the final destination of their holidays.

The average expenditures of tourists during their trips to Slovakia is very low, i.e. approx. 270 EUR per trip of an inbound tourist in 2016 (Statistical Office of the Slovak Republic, 2016a, b). Accommodation represents a significant part of tourists' expenditures. Receipts from accommodation in Slovak inbound tourism accounted for approx. $186,388,000$ EUR in 2017. Bratislava as one of the eight Slovak regions attracts over $40 \%$ of foreign tourists visiting the country and generates over $40 \%$ of accommodation receipts (Statistical Office of the Slovak Republic, 2018 b, c). From this point of view, it can be hold for the most important touristic region of Slovakia. That is partly the reason Bratislava was chosen as the case study.

Consumer generated reviews can provide valuable information about the hotel sector performance in the Bratislava region as the inevitable part of the tourism product of the region. Bratislava can be considered the entrance gate to Slovakia due to very low international accessibility of other regions. The study introduces Bratislava and Slovakia to the academic circles more closely as the destinations are barely covered by tourism research and academic literature. Its results benefit the hotel managers and decision makers in Bratislava in revealing areas for improving hotels' performance that may lead to attracting inbound tourists staying a longer period of time and improving the online image of Bratislava hotel sector as formed by the online travelers' community. Detailed information about the hotel sector and inbound tourism of Slovakia and Bratislava is presented in Table 2 and Table 3.

Table 2. Accommodation establishments by type of accommodation (2017)

\begin{tabular}{lccc}
\hline Type of accommodation & Slovakia (SVK) & $\begin{array}{c}\text { Bratislava region } \\
\text { (BA) }\end{array}$ & BA / SVK (\%) \\
\hline Hotels $\left(1^{*}-5^{*}\right)$ & 651 & 101 & 15.5 \\
Guesthouses & 816 & 36 & 4.4 \\
Hostels & 315 & 14 & 4.4 \\
Cottages, Bungalows & 52 & - & - \\
Private rental properties & 723 & 14 & 1.9 \\
Other & 884 & 60 & 6.8 \\
Total & 3495 & 234 & 6.7 \\
\hline
\end{tabular}

Source: Adapted from Statistical Office of the Slovak Republic (2018b, c). 
Table 3. Inbound tourists in Slovakia and the Bratislava region by type of accommodation (2017)

\begin{tabular}{lcccc}
\hline $\begin{array}{l}\text { Type of } \\
\text { accommodation }\end{array}$ & $\begin{array}{c}\text { Number of } \\
\text { inbound } \\
\text { tourists (SVK }\end{array}$ & $\begin{array}{c}\text { \% of inbound } \\
\text { tourists (SVK) }\end{array}$ & $\begin{array}{c}\text { Number of } \\
\text { inbound } \\
\text { tourists (BA*) }\end{array}$ & $\begin{array}{c}\text { \% of inbound } \\
\text { tourists (BA) }\end{array}$ \\
\hline $5^{*} \& 4^{*}$ hotels & $1,025,374$ & 47.4 & 631,164 & 67.8 \\
$3^{*}$ hotels & 463,403 & 21.4 & 131,547 & 14.1 \\
$2^{*}$ hotels & 80,559 & 3.7 & 21,401 & 2.3 \\
$1^{*}$ hotels & 45,811 & 2.1 & 23,018 & 2.5 \\
Hotels in Total & $1,615,147$ & 74.6 & 807,130 & 86.7 \\
Guesthouses & 184,026 & 8.5 & 10,111 & 1.1 \\
Hostels & 69,373 & 3.2 & 23,903 & 2.6 \\
Cottages, Bungalows & 39,483 & 1.8 & - & - \\
Private rental & 32,877 & 1.5 & 1,513 & 0.2 \\
properties & & & & \\
Other & 168,602 & 7.8 & 60,065 & 6.5 \\
\hline
\end{tabular}

Source: Adapted from Statistical Office of the Slovak Republic (2018b, c).

*SVK - Slovakia; **BA - Bratislava Region

\section{METHODOLOGY}

The consumer generated reviews on TripAdvisor related to the evaluations of the hotels' performance in Bratislava were gathered between December 2017 and May 2018. Two types of data can be reached from Tripadvisor.com. While the first one consists of evaluations of hotel attributes and hotel's overall performance that are rated from 1 to 5 corresponding to evaluations from terrible to excellent respectively, the second type are freely expressed opinions written in the form of text by travelers. In addition, some other type of information such as demographic can be extracted too. In our study, the former type of data has been utilized including the hotel attributes of value, location, sleep quality, rooms, cleanliness and service and the hotels' overall performance attribute called the overall evaluation. As in the study of Jeong and Mindy Jeon (2008), the attributes' evaluations are directly accepted as hotels' performance indicators and subjected to the analysis.

Slovakia has considerable tourism potential but has received limited attention in the literature. It was selected as the case study because any similar data collection and analysis had never been undertaken in the area before. When the data collection began, there were 434 hotels in 67 various locations across Slovakia registered on Tripadvisor.com with over 33.000 user reviews. $90 \%$ of online reviews of hotels in Slovakia registered on TripAdvisor belonged to Bratislava hotels. In addition, Bratislava as the region including the capital of the country is at the same time the most 
visited region attracting $27 \%$ of tourists in total and $43 \%$ of foreign tourists visiting Slovakia (Statistical Office of the Slovak Republic, 2018c). The research sample was thus narrowed to 93 hotels located in Bratislava which still accounted for almost 29.700 reviews in December 2017. In order to minimize the missing data in the sample, the generic characteristics of the collected reviews were set as follows:

- $\quad$ Travel date between 2014 and 2018

- Overall rating and all specific ratings for the hotels were submitted, i.e. value, location, sleep quality, rooms, cleanliness, service were rated without an omission.

- At most one demographic data about the submitter of a review was missing, i.e. at most one out of age, nationality or gender.

The suitable reviews were then coded into an SPSS 24.0 version composing of a sample of 1404 reviews from 93 hotels in Bratislava, Slovakia. In order to clearly distinguish the overall evaluation as the hotel's overall performance attribute and the sub-categories of a hotel's performance including hotel attributes of value, location, sleep quality, rooms, cleanliness and service, the overall evaluation is called hotel performance attribute while the specific sub-categories' ratings are called hotel attributes in our study. In order to extract insights from the collected data, independent sample t-test, ANOVA and Factor analysis are employed. T-test and ANOVA are employed since some attributes are categorized, namely, age groups, hotel groups, years, gender and so on. Hence, t-test and ANOVA are suitably employed to determine whether any differences exist among groups based on each hotel attribute and the overall evaluation. In addition, Factor analysis is run in order to determine whether the overall evaluation as a hotel performance indicator is linked to any hotel attribute or not. As reported in the literature, some hotel attributes are not related to the overall evaluation.

\section{RESULTS}

While females accounted for 35 percent of reviewers, 65 percent were males. This does not represent the visitors' gender profile of Bratislava hotels. The prevailing percentage of males stems from the fact that $63 \%$ of submitters in the sample were couples and business travelers. Assuming that business travelers consist predominantly from males and in case of a couple travelling males are in charge of doing travel arrangements, i.e. review 
submission invitation is sent to their email addresses, males formed a higher proportion of the dataset. The way the attribute evaluation is influenced by an uneven share of genders leaves an open question for a future research.

The proportion of the age interval of either 18-24 or 65+ was less than ten percent, which accounted for 1.3 and 7.4 percent respectively. The leading age group of the submitters was 35-49 with 41 percent, followed by the age intervals of 25-34 and 50-64 with 25 percent each.

When travel type is concerned, most of the reviewers travelled as couples $(35 \%)$ or as business travelers $(28 \%)$. Remaining travel types were family, friends and solo, which summed up the remaining $37 \%$. The recorded data mostly came from the travel years 2014, 2015 and 2016 providing 91 percent of the dataset.

When travel season is considered, most of the submitters travelled in the spring $(39 \%)$ and summer time $(28 \%)$ followed by the fall and winter seasons (13 and 22 percent respectively). The leading hotel group which reviews mostly fitted the selected criteria was 4-star hotels accounting for $71 \%$ of the data. The remaining $28 \%$ comprises 3 -star (16\%), 5 -star $(12 \%)$ and 2-star hotels (1\%). While data consists of predominantly chain hotels (75\%), 25\% come from independent hotels. The representation of hotel classes and the dominance of hotel chains in the dataset is not meant to reflect the situation of the hotel sector in Bratislava but rather the usage of social platforms by hotels and their visitors. Significantly higher share of 4and 5-star hotels and hotel chains in the dataset is believed to be a result of more effective usage of social platforms by bigger international hotels in combination with their visitors' profile of tourists that are more frequent contributors to TripAdvisor.

Table 4. The significant attributes based on gender

\begin{tabular}{lclc}
\hline \multicolumn{2}{c}{ Female } & \multicolumn{2}{c}{ Male } \\
\hline Attributes & Average & Attributes & Average \\
Sleep Quality & 4.44 & Sleep Quality & 4.34 \\
Cleanliness & 4.51 & Cleanliness & 4.42 \\
Service & 4.41 & Service & 4.31 \\
\hline
\end{tabular}

In order to be more explicit, just significant results with summarizing tables including explanations are provided. In addition, short remarks describing what was conducted and found are provided. When all hotel 
attributes are concerned, there is a significant difference between males and females at the level of 0.05 . As seen in Table 4, females rate sleep quality, cleanliness and service higher than males on average.

When hotel attributes are examined with respect to age groups, sleep quality and location were found statistically significant at 0.05 . The subgroups for each attribute showing significant differences are summarized in Table 5. While travelers whose age is $>65$ rate higher than the other age groups when location is concerned, the travelers aged between 18 and 24 rate sleep quality higher than the other age groups. The average scores for each variable corresponding to each age group are presented in Table 5.

Table 5. The results of post-hoc test of Duncan for the hotel attributes of location and sleep quality

\begin{tabular}{|c|c|c|c|c|c|c|c|c|c|c|}
\hline Attributes & \multicolumn{5}{|c|}{ Location } & \multicolumn{4}{|c|}{ Sleep Quality } & \\
\hline Group & I & & & & II & I & II & & & \\
\hline Age & $18-24$ & $25-34$ & $35-49$ & $50-64$ & $>65$ & $18-24$ & $25-34$ & $35-49$ & $50-64$ & $>65$ \\
\hline Average & 4.00 & 4.28 & 4.28 & 4.28 & 4.60 & 4.67 & 4.13 & 4.45 & 4.36 & 4.37 \\
\hline
\end{tabular}

Taking into consideration the travel types, travel years and travel seasons, no statistically significant differences were found at 0.05 significance level. However, statistically significant differences based on hotel classification were revealed among hotel attributes with the exception of Location at the significance level of 0.05. The results of ANOVA test using Duncan Post-Hoc are summarized in Table 6 and Table 7.

Table 6. The results of hotel attributes of Value and Location based on hotel classification using Duncan Post Hoc test

\begin{tabular}{|l|l|l|l|l|l|l|l|}
\hline Attributes & \multicolumn{5}{|c|}{ Value } & \multicolumn{3}{c|}{ Location } \\
\hline Group & I & II & III & I \\
\hline Hotel Class & $2^{*}-3^{*}$ & $4^{*}$ & $5^{*}$ & $2^{*}-3^{*}-4^{*}-5^{*}$ & 4.44 & 4.66 \\
\hline Average & 3.73 & 4.04 & 4.75 & 4.39 & 4.40 & 49 & \\
\hline
\end{tabular}


Table 7. The results of other hotel attributes based on hotel classification using Duncan Post Hoc test

\begin{tabular}{|l|l|l|l|l|l|l|l|l|l|l|l|l|l|l|l|l|}
\hline Attributes & \multicolumn{10}{l|}{ Sleep Quality } & \multicolumn{10}{l|}{ Room } & \multicolumn{10}{l|}{ Cleanliness } & \multicolumn{1}{l|}{ Service } \\
\hline Group & I & II & III & IV & I & II & III & IV & I & II & III & IV & I & II & III & IV \\
\hline Hotel Class & $2^{*}$ & $3^{*}$ & $4^{*}$ & $5^{*}$ & $2^{*}$ & $3^{*}$ & $4^{*}$ & $5^{*}$ & $2^{*}$ & $3^{*}$ & $4^{*}$ & $5^{*}$ & $2^{*}$ & $3^{*}$ & $4^{*}$ & $5^{*}$ \\
\hline Average & 3.00 & 3.98 & 4.41 & 4.79 & 3.20 & 3.84 & 4.36 & 4.82 & 3.67 & 4.14 & 4.46 & 4.85 & 3.33 & 4.00 & 4.37 & 4.75 \\
\hline
\end{tabular}

As seen in Table 6, Location attribute shows no significant differences among the individual hotel classes when it comes to hotel's performance evaluation regarding its location. It seems that location of a hotel is evaluated independently with no regard to whether a visitor stayed in a 2-, 3-, 4- or a 5-star hotel. Well located hotels may receive a high rating on the performance attribute of Location even though they are only 2-star and vice versa. There are however significant differences in relation to Value. Based on the results, the travelers' evaluations concerning the value they get for the price they pay do not differ very much between 2 and 3-star hotels. When it comes to 4 and 5-star hotels, the hotels' performance evaluations regarding the Value increase significantly along with the hotel class.

The performance evaluations of hotels regarding sleep quality, room, cleanliness and service summarized in Table 7 seem to differ significantly along with the hotel classifications. When hotel class rises from 2 to 5-star, the corresponding average scores for each attribute definitely increases. The results seem to indicate a problem in implementing the hotel classification standards in practice or in consumers' awareness of differences among hotel classes set by a classification system. Although the hotel classification system determines minimum requirements for each hotel class that may have impact on equipment of rooms, service at hotels and sleep quality, there is no logical reasoning why Cleanliness should differ depending on the hotel class. It is rather a basic necessity for each hotel regardless the hotel class.

In case of the overall evaluation as hotels' overall performance attribute, the same statistical analyses were conducted. No variables other than hotel classification were found statistically significant for the overall evaluation at the significance level of 0.05 . Based on the results presented in Table 8 it is obvious that the overall hotel performance evaluation reflects 
the hotel class, i.e. the higher the hotel class is, the higher the average performance evaluation score would be. Although the average evaluation scores for the overall performance of hotels are over the average (starting from 3.13 out of 5), luxury hotels seem to perform much higher in comparison to 2 and 3-star hotels.

Table 8. Overall evaluation results based on Duncan Post-Hoc test

\begin{tabular}{|l|l|l|l|l|}
\hline Group & I & II & III & IV \\
\hline Hotel Class & $2^{*}$ & $3^{*}$ & $4^{*}$ & $5^{*}$ \\
\hline Average & 3.13 & 3.97 & 4.35 & 4.75 \\
\hline
\end{tabular}

Factor-analysis was run in order to determine which hotel attributes are statistically related to each other. With $76.5 \%$ variance explanation value, two rotated groups of factors including different sets of attributes are presented in Table 9. The table was simplified by writing down the significant attributes only with its corresponding factor loadings. While Factor 1 includes five hotel attributes, namely value, sleep quality, room, cleanliness and service plus the overall evaluation, Factor 2 just contains one hotel performance attribute of Location.

Table 9. Factor analysis results

\begin{tabular}{|l|l|l|l|l|l|l|}
\hline Factor 1 & Overall & Value & $\begin{array}{l}\text { Sleep } \\
\text { Quality }\end{array}$ & Room & Cleanliness & Service \\
\hline $\begin{array}{l}\text { Factor } \\
\text { Loadings }\end{array}$ & 0.92 & 0.82 & 0.82 & 0.87 & 0.84 & 0.81 \\
\hline Factor 2 & Location & & & & & \\
\hline $\begin{array}{l}\text { Factor } \\
\text { Loadings }\end{array}$ & 0.91 & & & & & \\
\hline
\end{tabular}

The hotels' overall performance evaluation is a function of five performance attributes composing of weighted attributes in the form of linear functional form. It is assumed that if linearity exists between overall evaluation and other performance attributes, factor analysis can be used to represent that functionality. After running factor analysis, the variance explanation portion was $76.5 \%$, which is highly acceptable and represents linearity. However, the unexplained part, which is almost $23 \%$, is nonlinear. Therefore, overall evaluation is a function of value, sleep quality, cleanliness, room and service. On the other hand, location is another 
independent dimension that cannot be associated with overall evaluation and other performance attributes. The non-linearity part with $23 \%$ variation still needs to be studied. Therefore, the Overall evaluation as a hotel performance measure composes of two main constituents, linear and nonlinear respectively. In further research studies, these could be modelled based on the proposed six hotel attributes.

\section{DISCUSSION OF RESULTS AND CONCLUSION}

Consumer generated media gain momentum in the assessment of hotels and their performance. Their in-depth analysis might provide useful insights to hotel service quality as the driver of hotels' performance. In this study, the travelers' evaluations of Bratislava hotels on the tripadvisor.com website were examined. Six hotel attributes and an overall evaluation attribute were accepted to be the online representations of hotels' performance. Statistical analysis such as t-test, ANOVA and factor analysis were used in order to analyze which attributes determine the overall hotel's performance evaluation and any possible relations to demographic, trip and hotel characteristics. To our best belief such a complex analysis of what the hotel performance attributes are influenced by using the standardized data on TripAdvisor is yet missing. Only partial information is provided by a few studies concentrating on one group of variables. The study is meant to provide an example for extracting insights from big data that might turn into implementable recommendations aimed at improving performance of hotels in Bratislava, Slovakia.

The analysis of any relations between hotels' performance attributes evaluation and demographic characteristics of reviewers revealed significant differences in performance attributes assessment among different genders and age groups. Based on the results, women seem to rate sleep quality, cleanliness and service slightly higher than men while their average given score is rather high (over 4.41 out of 5). The representation of females in the sample was however considerably lower than of males. Although it is generally assumed that business travelers are predominantly male and that men usually do the travel arrangements on behalf of his partner or family, which makes them to receive the TripAdvisor review submission invitation, it raises the question about the influence of uneven share of gender upon the online ratings and about the representativeness of evaluations submitted on behalf of a couple or a whole family. When age is concerned, some age groups showed significant differences when evaluating the hotels' performance in relation to sleep quality and location. 
While $65+$ group submits higher average score for location than other groups, 18-24 age group have higher average score for sleep quality than other age groups do. These findings leave space for a further research about the reasons behind the differences among various demographic groups.

The trip characteristics taken into consideration when researching the relation with hotels' performance attribute evaluation were travel year, travel season and travel type. The analysis revealed no significant differences in performance evaluation in relation to those variables. This contradicts the results of the study of Kantarci et al. (2017) analyzing TripAdvisor reviews of hotels in Kyrgyzstan between 2012 and 2016 in relation to travel type, season and year. Applying the Log-Linear model, the work found a significant relation between the combination of travel type and travel season with hotel attributes. According to the authors, sleep quality, location, room and cleanliness attributes are the most important factors for solo travelers in winter, while service and value are the most influential in online ratings of business, solo and couple travelers.

Hotel class, as the only significant hotel characteristic, was found the most influential with regard to hotels' overall and specific performance attributes evaluation with impact on the overall, as well as specific ratings, with the exception of location. The average performance score for the Location attribute is very high reaching over 4.39 out of 5 , which indicates that Bratislava hotels registered on TripAdvisor regardless of hotel class are all in a convenient central location, thus all the hotels scoring very high on average. The insignificant differences of average performance scores among hotel classes mean that hotels' performance in regard to its location is evaluated independently from hotel class. This supports the findings of Jeong and Mindy Jeon (2008) that imply that "convenience of location of hotels from the guest's interest points is a key element in hotel choice regardless of hotel class" (Jeong \& Mindy Jeon, 2008, p. 135).

The Value performance was another attribute that was significantly influenced by the hotel class. Regarding the hotels' performance in relation to the value compared to the price of the services, the online evaluations do not differ significantly between 2 and 3-star hotels with average performance score of 3.73, which is slightly over average. Even though the hotel class increases from 2 to 3 -star, the extra service of a higher class is balanced by a higher price and, as a result, the value perceived by the consumer does not change significantly. When it comes to value evaluation in 4 and 5-star hotels, luxury hotels have higher average performance ratings compared to lower classes but there is a big difference between the 
average scores of 4-star hotels (4.04) and 5-star hotels (4.75). The results contradict the findings of Jeong and Mindy Jeon (2008) whose research found value to be an attribute independent from the hotel class. Giving an example of a 4-star hotel, the authors stated that a hotel is considered valued only if it matches the accommodation standards of its star ratings and its high room rate.

On the other hand, the results of the current study indicate that the higher hotel class is, it may be perceived as a plus value. Even though the prices of 5-star hotels rise, the perceived value the consumers receive in return is considerably higher than the price increase and the performance attribute of Value is rated with a higher score. This leaves a question mark that needs to be further investigated, e.g. whether the big perception gap between the value offered by 4 and 5 -star hotels is caused by a broad difference in services of the hotel classes, by the price policy of Bratislava hotels or simply by a psychological effect of "staying in a 5-star hotel". Almost $68 \%$ of inbound tourists visiting Bratislava chose to stay in luxury 4 and 5-star hotels, which implies that the majority of tourists who visit the region prefer to get a higher value for a higher price, instead of advantageous prices encompassing lower value and service quality. It would, therefore, be appropriate for hotels in Bratislava to maintain or improve the offered value to succeed on the market, especially in the fierce competition of neighboring countries, instead of concentrating on price reductions as a means of gaining a competitive advantage.

In relation to the performance attributes of sleep quality, room, cleanliness and service, significant differences among the individual hotel classes were observed as well. The sleep quality, room and service of hotels are influenced by the hotel classification standards that set requirements for each hotel class. It is natural that the quality of service, room comfort and equipment and even sleep quality will differ based on the hotel class. Given that the consumers are aware of the standard differences among the hotel classes, there is no reason for the attributes to be evaluated according to the hotel class. In this study, however, the hotels' performance evaluations of those three attributes were dependent on the hotel class, i.e. as the hotel class rose from 2 to 5 -star, the performance attributes were evaluated significantly higher on average. The 2 and 3-star Bratislava hotels shall pay more attention to improving their performance, especially in relation to room and service attributes, as these were found to be the most important hotel attributes determining the online ratings by consumers (Rhee \& Yang, 2015; Zhang \& Verma, 2017; Jang et al., 2018). 
Although the hotel classification system determines minimum requirements for each hotel class that may have impact on rooms' equipment, hotel's service and sleep quality, there is no logical reasoning why Cleanliness should differ depending on the star rating. Every hotel is bound to provide accommodation services in clean and hygienic conditions whether it is 2 or 5 -star. The perceived performance of Bratislava hotels regarding their cleanliness decreases significantly with each lower hotel class, with 2-star hotels' performance average evaluation of 3.67. The issue requires immediate attention of managers of 2 and 3-star hotels that seem to fail fulfilling the basic requirements of cleanliness in their establishments. The findings agree with results of the study of Jeong and Mindy Jeon (2008) who discovered a similar problem among New York hotels in 2006.

Although the hotels in Bratislava perform quite well in general, still space for improvements has been discovered. The overall evaluation of the hotels' performance changed parallel with the hotels' star classification as well. The higher the hotel class, the higher the hotel's average performance evaluation score. The findings confirm the results of Jeong and Mindy Jeon (2008), whose research found that luxury hotels perform better than lower rated hotels; as well as the results of Zhang and Verma (2017) who found that hotels with the most consistent service also had the highest ratings online. The dependence of hotels' ratings of their overall performance on the hotel class implies that the hotel classification system in Slovakia is either not well implemented into practice or not communicated sufficiently to the consumers. The official hotel classification system sets minimal requirements for each hotel class that needs to be fulfilled. In theory, if hotels meet the necessary requirements and hotel visitors are familiar with the standards and differences in the level of service among individual classes, the performance of the hotels should be evaluated regardless of the hotel class. In other words, even a 2-star hotel can show excellent performance if it meets its class requirements, room rate and consumers' expectations formed accordingly. The results of Bratislava hotels' performance analysis however oppose the theory. The reasons cannot be derived from the current study and would need a closer investigation.

After running both ANOVA and the factor analysis, location was not found to be a significant hotel attribute whatsoever. It appeared to be an independent factor which does not have any impact on the hotels' overall performance evaluation within the extent of the analysis. Hence, the overall evaluation is a linear function of the hotel performance attributes of value, sleep quality, room, cleanliness and service. In order to increase the overall evaluations through online consumer generated reviews, the hotels must 
increase their performance regarding the five hotel attributes. The factor analyses further showed that the correlation among the hotels' overall evaluation and other hotel performance attributes is very high with factor loadings between 0.81 and 0.92 . It contradicts the findings of Racherla et al. (2013) whose findings indicated that the overall evaluation ratings may not be suitable indicators of perceived service quality and customer satisfaction due to very low correlation among the overall rating and specific ratings. The current study on the other hand revealed high representativeness of numeric ratings of the overall hotels' performance evaluations in CGRs.

\section{Implications and limitations of the study}

The study contributes to the hotels' performance literature by elaborating on the consumers' perspective of the matter through their expressions on the Internet and broadly used social platforms representing real-time big data. Using the mentioned statistical methods, the research provided an example of extracting valuable information from huge amount of data on social platforms. These can be easily applied by hotels' management for monitoring and improving hotels' performance. Benefitting from the CGRs as representations of consumers' perspective on the hotels' performance, the factors it is influenced by and dependent on is of utter importance as the online ratings of hotels through CGR have been proved to be directly linked to hotels' financial performance through influencing their average daily rate (Lynch, 2012), room sales (Ye et al., 2009, Ögüt \& Onur Taş, 2012), price premium (Yacouel \& Fleischer, 2012) and online bookings (Ye et al., 2011). The information regularly extracted from TripAdvisor data provide an insight about a hotels' performance regarding their service, rooms, location, cleanliness, value and sleep quality and about the differences in perceived performance of hotels in those areas among various demographic groups, travel seasons, types of holidaymakers, hotel classes etc. Applying that information in fields such as product innovation, service quality improvement or market segmentation and targeting can consequently lead to improving the hotels' overall performance. As stated by Jang et al. (2018) better understanding of consumers leads to improvements of customer satisfaction and hotel performance.

In the context of Slovakia, the study generates a picture about the performance of Bratislava hotels in general and in relation to the individual hotel performance attributes. It also provides more detailed information about the differences in evaluation of those attributes by various demographic groups and hotel classes. Several problematic areas that need 
the attention of hotel managers and sector decision makers were uncovered. Especially, improving the hotels' performance when it comes to service, room and cleanliness attributes that are highly influential can help hotels and the hotel sector in Bratislava to improve their overall performance as evaluated by the online community that forms the online image of a destination (Singh et al., 2016) and influences the travelers' choices (Hays et al., 2013; Munar \& Jacobsen, 2014). As neither Bratislava nor Slovakia has ever been a subject of a similar research before, the study provides unique insight on tourism development in general and hotel sector in particular in the region, which can be further elaborated in comparison to its competitors.

As it was already mentioned in the result section of the study, the analysis was conducted upon a sample with a highly uneven distribution of genders and hotel chains. It would therefore require an additional attention to find out how big influence on the acquired results such a disproportionality has. One of the main limitations of the study includes the fact, that the performance evaluation was investigated only among the review submitter community while the representativeness of such a sample from all hotel service consumers remains questionable. In this study, the specific hotel performance attributes' influence on the overall performance evaluation was investigated but it did not answer the question of the relative importance of the attributes. Furthermore, the performance attributes used in the study were pre-defined by TripAdvisor and thus may not fully cover the main aspects of hotels performance from the consumers' perspective. As the needs of consumers, as well as the importance ascribed to the attributes may change over time, it could be suitable to combine the research with a frequency analysis of CGRs using text mining techniques to verify the accuracy of the pre-defined attributes on TripAdvisor.

\section{REFERENCES}

aices.sk (2019). Ministerstvo Dopravy a Výstavby SR. Retrieved June 25, 2019, from https://aices.sk/partneri/ministerstvo-dopravy-a-vystavby-sr/

Al Khattab, S. A., \& Aldehayyat, J. S. (2011). Perceptions of service quality in Jordanian hotels. International Journal of Business and Management, 6(7), 226-233.

Atkinson, H., \& Brander Brown, J. (2001). Rethinking performance measures: assessing progress in UK hotels. International Journal of Contemporary Hospitality Management, 13(3), 128-136.

Ayeh, J. K., Au, N., \& Law, R. (2013). “Do we believe in TripAdvisor?" Examining credibility perceptions and online travelers' attitude toward using user-generated content. Journal of Travel Research, 52(4), 437-452. 
Banerjee, S., \& Chua, A. Y. (2016). In search of patterns among travellers' hotel ratings in TripAdvisor. Tourism Management, 53, 125-131.

Banker, R. D., Potter, G., \& Srinivasan, D. (2005). Association of nonfinancial performance measures with the financial performance of a lodging chain. Cornell Hotel and Restaurant Administration Quarterly, 46(4), 394-412.

Bergin-Seers, S., \& Jago, L. (2007). Performance measurement in small motels in Australia:(Funded by the Sustainable Tourism Co-operative Research Centre). Tourism and Hospitality Research, 7(2), 144-155.

Central Intelligence Agency (2019). The World Facebook - Slovakia. Retrieved July 25, 2019, from https://www.cia.gov/library/publications/the-world-factbook/geos/lo.html

Chen, F. H., Hsu, T. S., \& Tzeng, G. H. (2011). A balanced scorecard approach to establish a performance evaluation and relationship model for hot spring hotels based on a hybrid MCDM model combining DEMATEL and ANP. International Journal of Hospitality Management, 30(4), 908-932.

Chua, A. Y., \& Banerjee, S. (2013). Reliability of reviews on the Internet: The case of TripAdvisor. In World Congress on Engineering \& Computer Science (pp. 453-457). York.

Cronin Jr, J. J., \& Taylor, S. A. (1992). Measuring service quality: A reexamination and extension. Journal of marketing, 56(3), 55-68.

Cronin Jr, J. J., \& Taylor, S. A. (1994). SERVPERF versus SERVQUAL: Reconciling performance-based and perceptions-minus-expectations measurement of service quality. Journal of Marketing, 58(1), 125-131.

culture.gov.sk (2019). Minsterstvo Kultúry Slovenskej Republiky. Retrieved June 24, 2019, from http://www.culture.gov.sk/ministerstvo/ministerstvo-278.html

Devi Juwaheer, T. (2004). Exploring international tourists' perceptions of hotel operations by using a modified SERVQUAL approach-a case study of Mauritius. Managing Service Quality: An International Journal, 14(5), 350-364.

European Commission (2017). Annual Report on Tourism 2017 - Slovakia. Retrieved June 24, 2019, from https://ec.europa.eu/

Evans, N. (2005). Assessing the balanced scorecard as a management tool for hotels. International Journal of Contemporary Hospitality Management, 17(5), 376-390.

Fitzgerald, L., Johnston, R., Brignall, T. J., Silvestro, R., \& Voss, C. (1991). Performance Measurement in Service Businesses (Vol. 69). London: Chartered Institute of Management Accountants.

Gretzel, U., \& Yoo, K. H. (2008). Use and impact of online travel reviews. Information and Communication Technologies in Tourism, 2008, 35-46.

Harrington, D., \& Akehurst, G. (1996). Service quality and business performance in the UK hotel industry. International Journal of Hospitality Management, 15(3), 283-298.

Hays, S., Page, S. J., \& Buhalis, D. (2013). Social media as a destination marketing tool: its use by national tourism organisations. Current Issues in Tourism, 16(3), 211-239.

Jang, S., Liu, T., Kang, J. H., \& Yang, H. (2018). Understanding important hotel attributes from the consumer perspective over time. Australasian Marketing Journal (AMJ), 26(1), 23-30.

Jeong, M., \& Mindy Jeon, M. (2008). Customer reviews of hotel experiences through consumer generated media (CGM). Journal of Hospitality \& Leisure Marketing, 17(12), 121-138.

Kantarci, K., Basaran, M. A., Ozyurt, P. M. (2017). Determining hotel performance through consumer generated travel 2.0 reviews: A case of Kyrgyzstan. Manas Sosyal Arastirmalar Dergisi, 6(5), 131-145. 
Kaplan, R. S., \& Norton, D. P. (1992). The balanced scorecard: Measures that drive performance. Harvard Business Review, 70(1), 71-79.

King, R. A., Racherla, P., \& Bush, V. D. (2014). What we know and don't know about online word-of-mouth: A review and synthesis of the literature. Journal of interactive marketing, 28(3), 167-183.

Kollberg, B., Elg, M., \& Lindmark, J. (2005). Design and implementation of a performance measurement system in Swedish health care services: a multiple case study of 6 development teams. Quality Management in Healthcare, 14(2), 95-111.

Lee, H. A., Law, R., \& Murphy, J. (2011). Helpful reviewers in TripAdvisor, an online travel community. Journal of Travel \& Tourism Marketing, 28(7), 675-688.

Lynch, J. (2012). Online review reputation management trends for hotels in 2012. Sabre Hospitality Solutions.

Melián-González, S., Bulchand-Gidumal, J., \& González López-Valcárcel, B. (2013). Online customer reviews of hotels: As participation increases, better evaluation is obtained. Cornell Hospitality Quarterly, 54(3), 274-283.

Miguéns, J., Baggio, R., \& Costa, C. (2008). Social media and tourism destinations: TripAdvisor case study. Advances in Tourism Research, 26(28), 1-6.

Ministry of Transport and Construction of the Slovak Republic (2013). Stratégia rozvoja cestovného ruchu do roku 2020. Retrieved June 25, 2019, from https://www.mindop.sk/ministerstvo-1/cestovny-ruch-7/legislativa-a-koncepcnedokumenty/koncepcne-dokumenty/strategia-rozvoja-cestovneho-ruchu-do-roku2020

Molinillo, S., Ximénez-de-Sandoval, J. L., Fernández-Morales, A., \& Coca-Stefaniak, A. (2016). Hotel assessment through social media: The case of TripAdvisor. Tourism \& Management Studies, 12(1), 15-24.

Munar, A. M., \& Jacobsen, J. K. S. (2014). Motivations for sharing tourism experiences through social media. Tourism management, 43, 46-54.

Narangajavana, Y., \& Hu, B. (2008). The relationship between the hotel rating system, service quality improvement, and hotel performance changes: A canonical analysis of hotels in Thailand. Journal of quality assurance in hospitality \& tourism, 9(1), 34-56.

Nasution, H. N., \& Mavondo, F. T. (2008). Customer value in the hotel industry: What managers believe they deliver and what customer experience. International Journal of Hospitality Management, 27(2), 204-213.

Ögüt, H., \& Onur Taş, B. K. (2012). The influence of internet customer reviews on the online sales and prices in hotel industry. The Service Industries Journal, 32(2), 197-214.

Öz, M. (2015). Social media utilization of tourists for travel-related purposes. International Journal of Contemporary Hospitality Management, 27(5), 1003-1023.

Padma, P., \& Ahn, J. (2020). Guest satisfaction \& dissatisfaction in luxury hotels: An application of big data. International Journal of Hospitality Management, 84, 102318.

Parasuraman, A., Berry, L. L., \& Zeithaml, V. A. (1991). Refinement and reassessment of the SERVQUAL scale. Journal of Retailing, 67(4), 420-450.

Parasuraman, A., Zeithaml, V. A., \& Berry, L. L. (1988). Servqual: A multiple-item scale for measuring consumer perc. Journal of Retailing, 64(1), 12-40.

Phillips, P., \& Louvieris, P. (2005). Performance measurement systems in tourism, hospitality, and leisure small medium-sized enterprises: a balanced scorecard perspective. Journal of Travel Research, 44(2), 201-211.

Racherla, P., Connolly, D. J., \& Christodoulidou, N. (2013). What determines consumers' ratings of service providers? An exploratory study of online traveler reviews. Journal of Hospitality Marketing \& Management, 22(2), 135-161. 
Ramsaran-Fowdar, R. R. (2007). Developing a service quality questionnaire for the hotel industry in Mauritius. Journal of Vacation Marketing, 13(1), 19-27.

Rhee, H. T., \& Yang, S. B. (2015). Does hotel attribute importance differ by hotel? Focusing on hotel star-classifications and customers' overall ratings. Computers in Human Behavior, 50, 576-587.

SACR. (2013). Marketingová stratégia Slovenskej agentúry pre cestovný ruch na roky 2014 - 2020. Retrieved March 14, 2018, from https://www.mindop.sk/ministerstvo-1/cestovnyruch-7/legislativa-a-koncepcne-dokumenty/koncepcne-dokumenty/strategiarozvoja-cestovneho-ruchu-do-roku-2020

Sainaghi, R. (2010). Hotel performance: state of the art. International Journal of Contemporary Hospitality Management, 22(7), 920-952.

Sigala, M., Christou, E., \& Gretzel, U. (Eds.). (2012). Social media in travel, tourism and hospitality: Theory, practice and cases. Ashgate Publishing, Ltd.

Singh, D., Torres, E. N., \& Robertson-Ring, A. (2016). Playing for first place: An analysis of online reviews and their impact on local market rankings. Advances in Hospitality and Tourism Research (AHTR), 4(1), 32-51.

Slovakia.travel (2018). Facts about Slovakia. Retrieved April 1, 2018, from http://slovakia.travel/en/about-slovakia/facts

Slovakia.travel (2019). Mobile Applications. Retrieved June 21, 2019, from https://www.mindop.sk/ministerstvo-1/cestovny-ruch-7/legislativa-a-koncepcnedokumenty/koncepcne-dokumenty/strategia-rozvoja-cestovneho-ruchu-do-roku2020

Statistical Office of the Slovak Republic (2018a). Ubytovacia štatistika CR na Slovensku. Štruktúra návštevníkov 1998 - 2017. Retrieved June 15, 2019, from https://www.mindop.sk/ministerstvo-1/cestovny-ruch-7/statistika/ubytovaciastatistika/2018

Statistical Office of the Slovak Republic (2018b). Ubytovacia štatistika CR na Slovensku. Kapacity a výkony UZ CR 2014 - 2017. Retrieved June 15, 2019, from https://www.mindop.sk/ministerstvo-1/cestovny-ruch-7/statistika/ubytovaciastatistika/2018

Statistical Office of the Slovak Republic (2018c). Ubytovacia štatistika CR na Slovensku. Kapacity a výkony UZ CR 2014 - 2017/Kraje. Retrieved June 15, 2019, from https://www.mindop.sk/ministerstvo-1/cestovny-ruch-7/statistika/ubytovaciastatistika/2018

Statistical Office of the Slovak Republic (2016a). Zahraničný návštevníci SR - hraničné priechody. Retrieved February 18, 2018, from http://www.telecom.gov.sk/index/index.php?ids=213792

Statistical Office of the Slovak Republic (2016b). Zahraničný návštevníci SR - turistické centrá - podla krajiny pôvodu. Retrieved February 18, 2018, from http://www.telecom.gov.sk/index/index.php?ids=213792

Stefano, N. M., Casarotto Filho, N., Barichello, R., \& Sohn, A. P. (2015). A fuzzy SERVQUAL based method for evaluated of service quality in the hotel industry. Procedia CIRP, 30, 433-438.

Touminen, P. (2011). The influence of TripAdvisor consumer-generated travel reviews on hotel performance. University of Hertfordshire Business School Working Paper, Presented at the 19th annual Frontiers in Service Conference (2011), pp. 1-11.

Vermeulen, I. E., \& Seegers, D. (2009). Tried and tested: The impact of online hotel reviews on consumer consideration. Tourism management, 30(1), 123-127. 
Wilkins, H., Merrilees, B., \& Herington, C. (2007). Towards an understanding of total service quality in hotels. International Journal of Hospitality Management, 26(4), 840853.

World Economic Forum (2018). The Travel \& Tourism Competitiveness Report 2017. Retrieved January 18, 2018, from https://www.weforum.org/reports/the-travel-tourismcompetitiveness-report-2017

World Travel \& Tourism Council (2018). Travel \& Tourism Economic Impact 2018 Slovakia. Retrieved June 20, 2019, from https://www.wttc.org/economicimpact/country-analysis/country-reports/

Xie, K. L., Chen, C., \& Wu, S. (2016a). Online consumer review factors affecting offline hotel popularity: Evidence from TripAdvisor. Journal of Travel \& Tourism Marketing, 33(2), 211-223.

Xie, K. L., Zhang, Z., Zhang, Z., Singh, A., \& Lee, S. K. (2016b). Effects of managerial response on consumer eWOM and hotel performance: Evidence from TripAdvisor. International Journal of Contemporary Hospitality Management, 28(9), 2013-2034.

Yacouel, N., \& Fleischer, A. (2012). The role of cybermediaries in reputation building and price premiums in the online hotel market. Journal of Travel Research, 51(2), 219-226.

Ye, Q., Law, R., \& Gu, B. (2009). The impact of online user reviews on hotel room sales. International Journal of Hospitality Management, 28(1), 180-182.

Ye, Q., Law, R., Gu, B., \& Chen, W. (2011). The influence of user-generated content on traveler behavior: An empirical investigation on the effects of e-word-of-mouth to hotel online bookings. Computers in Human Behavior, 27(2), 634-639.

Yilmaz, I. (2009). Measurement of service quality in the hotel industry. Anatolia, 20(2), 375386.

Yoo, K. H., Lee, K. S., \& Gretzel, U. (2007, January). The role of source characteristics in eWOM: What makes online travel reviewers credible and likeable. In Proceedings of the 14th international ENTER conference in Ljubljana, Slovenia (pp. 23-34).

Yoo, K. H., Lee, Y., Gretzel, U., \& Fesenmaier, D. R. (2009). Trust in travel-related consumer generated media. Information and communication technologies in tourism, 2009, 49-59.

Zhang, J. J., \& Verma, R. (2017). What matters most to your guests: An exploratory study of online reviews. Cornell Hospitality Report, 17(4), 3-13.

Zigan, K., \& Zeglat, D. (2010). Intangible resources in performance measurement systems of the hotel industry. Facilities, 28(13/14), 597-610. 